\title{
STUDY OF THE PREVALENCE AND RISK FACTORS FOR LOW BACK PAIN IN TRUCK DRIVERS IN THE STATE OF SÃO PAULO, BRAZIL
}

\author{
Silvia Ferreira Andrusaitis, Reginaldo Perilo Oliveira, Tarcísio Eloy P. Barros \\ Filho
}

\begin{abstract}
Andrusaitis SF, Oliveira RP, Barros Filho TEP. Study of the prevalence and risk factors for low back pain in truck drivers in the state of São Paulo, Brazil. CLINICS. 2006;61(6):503-10.
\end{abstract}

OBJECTIVE: To investigate the prevalence of low back pain in truck drivers and check for possible risk factors related to the presence of low back pain.

METHODS: A questionnaire was developed including personal factors such as age, practice of physical and sports activities, general health habits, occupation-related issues, and factors associated with low back pain. The body mass index (ratio of body weight to the square of height, $\mathrm{kg} / \mathrm{m}^{2}$ ) was calculated. Of 489 male truck drivers assessed, 410 were enrolled into the study. The statistical analysis was divided into 2 stages: descriptive analysis of data, and binary logistical regression, where the response (dependent) variable (presence of low back pain) was associated with each independent variable to check for correlation with low back pain.

RESULTS: Of the 410 truck drivers evaluated, 242 (59\%) presented with low back pain, while 168 (41\%) did not have low back pain. The only factor correlated with the presence of low back pain was the number of working hours; the other factors had no correlation with low back pain.

CONCLUSION: The prevalence of low back pain in truck drivers was 59\%. The number of working hours was the only variable associated with occurrence of low back pain, with an average of about 1 hour longer work time for drivers with low back pain compared to those without it and with an odds ratio of $1.07(P=0.026)$.

KEYWORDS: Cross-sectional studies. Men. Automotive vehicles. Low back pain. Risk factors.

\section{INTRODUCTION}

Epidemiologic studies have shown that approximately $80 \%$ of the population has presented or will present an episode of low back pain during their active lives. ${ }^{1-6}$ Low back pain corresponds to over $50 \%$ of all musculoskeletal dysfunctions that cause chronic disabilities in industrialized countries, leading to expenses with treatments and absenteeism from work..$^{5,7-13}$

The Spine Group, Institute of Orthopedics and Traumatology, Hospital das Clínicas, São Paulo University Medical School - São Paulo/SP, Brazil.

E-mail: bibgodoi@usp.br

Received for publication on April 04, 2006.

Accepted for publication on May 16, 2006.
Low back pain or lumbar pain runs between the lower ribs and the glutei and can be related to multiple causes such as neoplasias; inflammatory and infectious diseases; systemic bone alterations; congenital abnormalities; degenerative, visceral, and psychogenic diseases; traumas; and mechanical causes. ${ }^{414}$ Occupational low back pain is related to the latter cause; the onset occurs while the individual is exerting occupational activities and therefore is related to certain working situations such as maintenance of the same posture for prolonged periods, repetitive movements, lifting of heavy objects, and tilting and torsion of the trunk. ${ }^{7,11,15,16}$ Moreover, not only can the exposure to risk factors lead to the onset of low back pain, but also the time of exposure to such factors can be a determinant of onset of low back pain. ${ }^{11,15,17,18}$ 
Among the many professionals affected by low back pain are motor vehicle drivers. Professional drivers present 3 times the risk for low back pain when compared to individuals involved in other occupational activities. ${ }^{19}$ This is explained not only by the above-mentioned mechanical factors but also by the presence of stress to which drivers are subjected in general, triggering musculoskeletal pain. ${ }^{20,21}$

Thus, given the high incidence of low back pain and the high costs of its consequences, studies have been conducted to estimate the most effective measures to control symptoms, although preventing the onset of low back pain can be more efficient and cost-effective. This requires knowledge of the triggering factors and the profile of the individuals who are more susceptible to the onset of low back pain. Studies on the prevalence and knowledge of risk factors for low back pain are important since they allow not only the determination of the impact of the disease on society or on a given social stratum, but they also help to organize health services and investments necessary for prevention and control of the symptoms. ${ }^{7,15}$

The objectives of this study were to investigate the prevalence of low back pain in truck drivers and to check for possible risk factors related to the presence of low back pain.

\section{METHODS}

A total of 410 truck drivers with over 1 year of professional experience who drove on Sao Paulo State Castello Branco, Senator Jose Ermirio de Moraes, and Raposo Tavares highways between March and November 2003 spontaneous agreed to participate in the study by signing an informed consent form. The exclusion criteria were having low back pain prior to entrance into the profession or having had low back pain of traumatic origin.

The subjects were evaluated using a questionnaire developed for this study and by the measurement of their weights and heights using an anthropometric balance in order to calculate the body mass index (BMI) by dividing the body weight $(\mathrm{kg})$ by the square of the height $\left(\mathrm{m}^{2}\right)^{22}$

The first 2 months of the study were used to develop and validate the questionnaire with the most appropriate and understandable terms to be explained to the truck drivers. Then, a 2-part questionnaire was applied. The first part addressed personal factors (such as age, ethnic group, skin color, physical and sports activity, and general health habits) and occupation-related issues (such as work period, leisure time, length of time in the profession, and self-employed or employee). The second part addressed factors related to low back pain, such as presence, type, duration, and frequency of pain to characterize activityrelated back pain. All questions were answered directly by the truck drivers, except for the items concerning skin color, which were recorded by one of the authors from visual observation.

Once the questionnaire was completed, the weight $(\mathrm{kg})$ and height $(\mathrm{m})$ of each participant was measured, and the body mass index (BMI, $\mathrm{kg} / \mathrm{m}^{2}$ ) was calculated.

One of the authors performed all evaluations, and nurse attendants measured the weights and heights of the participants.

The question asked of the truck drivers to check for low back pain was as follows: "While exerting your activity as a professional truck driver, have you experienced or did you use to experience low back pain?", where low back pain was defined as a pain between the lower ribs and the gluteal fold, but is not related to traumas or falls., ${ }^{4,14}$ The answers were divided into 2 categories (Yes and No), each Yes answer being subdivided into 3 categories according to the pain frequency, as follows: Experienced Pain, Occasional Pain, and Constant Pain.

\section{Statistical Analysis}

The response (dependent) variable adopted in this study was the presence or absence of low back pain, in order to estimate the prevalence of low back pain in truck drivers. The number of years of professional work, nature of work (self-employed or employee), hours of sleep at night, hours worked during the day, practice of physical or sports activity (yes or no), ethnic group, smoking, alcohol consumption, age, weight, height, and BMI value variables were analyzed to investigate to what extent these items might be risk factors for triggering low back pain, and also to draw a profile of these professionals. Following the descriptive analysis of the study results, a binary logistical regression model using the maximum verisimilitude method was performed, ${ }^{23}$ with the response (dependent) variable being the presence/absence of low back pain, and the explanatory (independent) variables being number of years of professional work, nature of work (self-employed or employee), hours of sleep at night, hours worked during the day, practice of physical or sports activity (yes or no), ethnic group, age, weight, height, and BMI value. The variables were selected using the forward procedure ${ }^{24}$ in order to determine which variables might be associated with the presence of low back pain.

Once the final model was adjusted, its suitability was checked using adjustment tests such as the chi square test 
for poor adjustment, and building residual standard deviation curves. The software used was STATA v. 6.

From the adjusted final model it was possible to obtain estimates of the prevalence and prevalence odds ratio for fixed values of the explanatory variables.

\section{RESULTS}

Of the 410 truck drivers evaluated, 242 (59\%) had low back pain, and 168 (41\%) did not have low back pain (Figure 1). Of the $242(59 \%)$ truck drivers with back pain, $31.2 \%$ had occasional pain, $18 \%$ had constant pain, and 9.8\% had experienced back pain some time in their professional lives. Of the factors investigated, the only factor significantly correlated with the presence of low back pain was the number of working hours ( $\mathrm{OR}=1,07, \mathrm{IC}=95 \%$, $[1,01 ; 1,13]$ (Table 1). The other factors considered as being associated with risk (age, anthropometric factors, ethnic factors, length of time in the profession, nature of work, hours of sleep at night, smoking, alcohol consumption, and practice of physical activity) showed no correlation with low back pain.

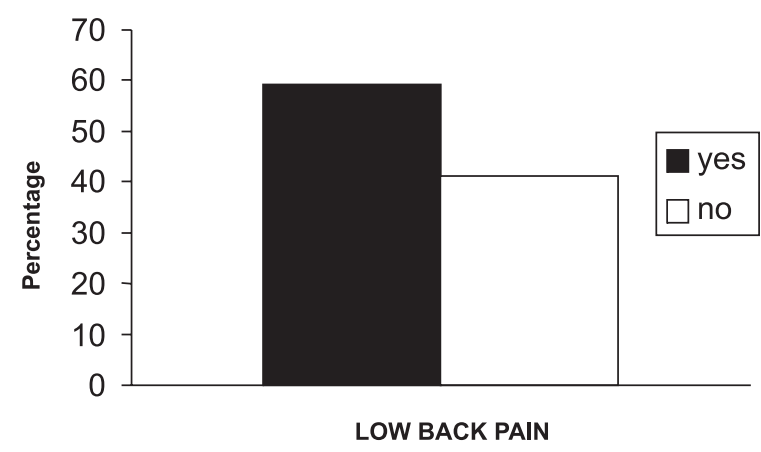

Figure 1 - Percent distribution of low back pain

Table 2 shows the average and median values, standard deviation, and maximum and minimum values observed as well as the sample size for the following variables: age (years), height $(\mathrm{m})$, BMI value $\left(\mathrm{kg} / \mathrm{m}^{2}\right)$, number of years in the profession, work hours and sleep hours, in each category (Yes and No) of low back pain.

The frequency distribution and percentages of smoking, alcohol consumption, nature of work, ethnic group and weekly frequency of physical activity practice variables in groups with and without low back pain are shown in Tables 3 and 4.

\section{DISCUSSION}

Several hypotheses were considered in this study. The first one was that the prevalence of low back pain in truck drivers would be high since, being professional drivers, they spend much of their time in the seated position and frequently twisting and bending their torsos, besides being subjected to the continuous vibration of the motor and having to load and unload the truck. According to the literature, these are relevant risk factors for the onset of low back pain. . $^{11-13,15,16,19,25-28}$

Other factors that were hypothesized to contribute to low back pain in truck drivers were sedentarism, improper diet, alcohol consumption, cigarette smoking, improper working conditions and work in excess, since all these characteristics are related to the profile of these professionals and are also related to the presence of low back pain. ${ }^{18,29-31}$

The 410 truck drivers were evaluated regarding these factors by questionnaire, and the result was that low back pain was present in $59.0 \%$ of these professionals and that among the probable risk factors analyzed, only the number of working hours was significantly correlated with the presence of low back pain.

The association of factors such as age, weight, height, BMI, smoking, and alcohol consumption with low back pain has produced controversial results as reported in the literature. ${ }^{32-36}$ The occurrence of low back pain among the general population increases with age and starts declining after 65 years of age, but its occurrence among younger individuals is not uncommon, although studies of specific populations have not shown any correlation between age and low back pain. $7,18,20,25,31,37$

The existence of a possible relationship between being overweight and low back pain is reasonable, since weight increases lead to overload on the spine, which can increase the pressure on the intervertebral disc and other structures of the spine, triggering pain. The same relationship can be observed concerning height. Individuals who, due to their heights, work under unfavorable ergonomic conditions have a higher probability to trigger low back pain..$^{37,38}$

Although in this study height and weight showed no relationship to the occurrence of low back pain, the BMI values found in the truck drivers studied was above an average $25 \mathrm{~kg} / \mathrm{m}^{2}$, which is regarded as overweight, and con-

Table 1 - Summary of significant results of logistic model adjustment

\begin{tabular}{lccccr}
\hline Predictor & Coefficient & Standard error & Z & $P$ & p ratio \\
\hline Constant & -0.26 & 0.30 & -0.88 & 0.377 & 0.026 \\
Work hours & 0.064 & 0.03 & 2.22 & 1.07 & $1.01 ; 1.13$ \\
\hline
\end{tabular}


Table 2 - Mean value, median value, standard deviation, maximum and minimum values observed and sample size of the following quantitative variables: age, height, BMI value, length of time in the profession, work hours, and sleep hours, according to the Yes and No categories of low back pain

\begin{tabular}{|c|c|c|c|c|}
\hline & & $\begin{array}{l}\text { LOW BACK PAIN - } \\
\text { NO }\end{array}$ & $\begin{array}{l}\text { LOW BACK PAIN - } \\
\text { YES }\end{array}$ & TOTAL \\
\hline \multirow[t]{6}{*}{ AGE (years) } & $\mathrm{n}$ & 168 & 242 & 410 \\
\hline & Mean & 40.73 & 39.78 & 40.17 \\
\hline & Median & 40.00 & 40.00 & 40.00 \\
\hline & Standard deviation & 10.46 & 9.98 & 10.17 \\
\hline & Minimum & 21 & 20 & 20 \\
\hline & Maximum & 69 & 65 & 69 \\
\hline \multicolumn{5}{|l|}{ HEIGHT (m) } \\
\hline & Mean & 1.71 & 1.72 & 1.72 \\
\hline & Median & 1.72 & 1.72 & 1.72 \\
\hline & Standard deviation & 0.06 & 0.07 & 0.06 \\
\hline & Minimum & 1.55 & 1.51 & 1.51 \\
\hline & Maximum & 1.90 & 1.93 & 1.93 \\
\hline \multicolumn{5}{|l|}{ BMI $\left(\mathrm{kg} / \mathrm{m}^{2}\right)$} \\
\hline & Mean & 26.54 & 27.02 & 26.83 \\
\hline & Median & 26.35 & 26.85 & 26.70 \\
\hline & Standard deviation & 3.68 & 3.84 & 3.78 \\
\hline & Minimum & 18.80 & 18.10 & 18.10 \\
\hline & Maximum & 37.90 & 38.60 & 38.60 \\
\hline \multicolumn{5}{|c|}{ TIME IN THE PROFESSION (years) } \\
\hline & Mean & 15.94 & 15.29 & 15.55 \\
\hline & Median & 14.50 & 15.00 & 15.00 \\
\hline & Standard deviation & 10.50 & 9.51 & 9.92 \\
\hline & Minimum & 1 & 1 & 1 \\
\hline & Maximum & 48 & 42 & 48 \\
\hline \multicolumn{5}{|c|}{ WORK HOURS } \\
\hline & Mean & 9.42 & 10.22 & 9.90 \\
\hline & Median & 9.00 & 10.00 & 10.00 \\
\hline & Standard deviation & 3.23 & 3.75 & 3.57 \\
\hline & Minimum & 2 & 1 & 1 \\
\hline & Maximum & 18 & 20 & 20 \\
\hline \multicolumn{5}{|c|}{ SLEEP HOURS } \\
\hline & Mean & 7.29 & 6.91 & 7.06 \\
\hline & Median & 8.00 & 7.00 & 8.00 \\
\hline & Standard deviation & 1.58 & 1.80 & 1.72 \\
\hline & Minimum & 3 & 3 & 3 \\
\hline & Maximum & 12 & 16 & 16 \\
\hline
\end{tabular}

sequently, is a risk known for other conditions such as diabetes mellitus and heart problems. Also, $77 \%$ of the truck drivers in this study did not practice any physical activity. Although this did not influence the triggering of low back pain, it does increase the risk for cardiovascular disease. ${ }^{22}$

As to smoking, although the literature confirms its association with low back pain, the causal mechanism is not fully elucidated. Smoking leads to decrease in perfusion and malnutrition of the paravertebral tissues and of the intervertebral disc, which can lead to a decrease in the stress resistance of the spine and interfere with lesion healing. Nicotine can also influence the central nervous system by changing the perception of pain, which would explain musculoskeletal pains in other regions of the body. ${ }^{29,30}$ Other issues could be involved, for instance, the smoking habit may be related to the fact that smokers tend to be sedentary and care less about their own health, so that the pro- file of smokers would be the risk factor for the occurrence of low back pain, and not merely the smoking habit.

Other factors to be noted are the length of time in the profession and the nature of work. Initially, it was thought that older truck drivers and self-employed truck drivers would show a higher occurrence of low back pain due to occupational stress over the years; self-employed workers do not receive benefits that are common for employees, such as days off, more definite work shifts, and medical assistance. However, the results did not confirm this hypothesis. The length of time in the profession was not correlated with the occurrence of low back pain, and the distribution of low back pain was similar among self-employed and employee truck drivers. These results could be due to have several possible factors. For example, older truck drivers who developed low back pain may have changed professions due to the pain, and those who remained in the 
Table 3 - Frequency distribution and percentages of smoking, alcohol consumption, and nature of work variables according to the Yes and No categories of low back pain

\begin{tabular}{|c|c|c|c|c|}
\hline \multicolumn{2}{|c|}{ Low back pain } & \multicolumn{2}{|c|}{ Smoking } & \multirow[t]{2}{*}{ Total } \\
\hline & & No & Yes & \\
\hline \multirow[t]{2}{*}{ No } & Frequency & 115 & 53 & 168 \\
\hline & Percentage & $68.5 \%$ & $31.5 \%$ & $100.0 \%$ \\
\hline \multirow[t]{2}{*}{ Yes } & Frequency & 165 & 77 & 242 \\
\hline & Percentage & $68.2 \%$ & $31.8 \%$ & $100.0 \%$ \\
\hline \multirow[t]{4}{*}{ Total } & Frequency & 280 & 130 & 410 \\
\hline & Percentage & $68.3 \%$ & $31.7 \%$ & $100.0 \%$ \\
\hline & & \multicolumn{2}{|c|}{ Alcohol consumption } & \\
\hline & & No & Yes & \\
\hline \multirow[t]{2}{*}{ No } & Frequency & 85 & 83 & 168 \\
\hline & Percentage & $50.6 \%$ & $49.4 \%$ & $100.0 \%$ \\
\hline \multirow[t]{2}{*}{ Yes } & Frequency & 131 & 111 & 242 \\
\hline & Percentage & $54.1 \%$ & $45.9 \%$ & $100.0 \%$ \\
\hline \multirow[t]{4}{*}{ Total } & Frequency & 216 & 194 & 410 \\
\hline & Percentage & $52.7 \%$ & $47.3 \%$ & $100.0 \%$ \\
\hline & & Nature & & \\
\hline & & Self-employed & Employee & \\
\hline \multirow[t]{2}{*}{ No } & Frequency & 52 & 116 & 168 \\
\hline & Percentage & $31.0 \%$ & $69.0 \%$ & $100.0 \%$ \\
\hline \multirow[t]{2}{*}{ Yes } & Frequency & 76 & 166 & 242 \\
\hline & Percentage & $31.4 \%$ & $68.6 \%$ & $100.0 \%$ \\
\hline \multirow[t]{2}{*}{ Total } & Frequency & 128 & 282 & 410 \\
\hline & Percentage & $31.2 \%$ & $68.8 \%$ & $100.0 \%$ \\
\hline
\end{tabular}

Table 4 - Frequency distribution and percentages of weekly frequency of physical activity practice and ethnic group variables according to the Yes and No categories of low back pain

\begin{tabular}{|c|c|c|c|c|c|c|c|c|}
\hline \multirow[t]{2}{*}{ Low back pain } & \multicolumn{7}{|c|}{ Weekly frequency - physical activity } & \multirow[t]{2}{*}{ Total } \\
\hline & & 0 & 1 & 2 & 3 & 4 & 5 & \\
\hline \multirow[t]{2}{*}{ No } & Frequency & 127 & 29 & 2 & 3 & 7 & & 168 \\
\hline & Percentage & $75.6 \%$ & $17.3 \%$ & $1.2 \%$ & $1.8 \%$ & & $4.2 \%$ & $100.0 \%$ \\
\hline \multirow[t]{2}{*}{ Yes } & Frequency & 189 & 35 & 4 & 7 & 2 & 5 & 242 \\
\hline & Percentage & $78.0 \%$ & $14.5 \%$ & $1.7 \%$ & $2.9 \%$ & $0.8 \%$ & $2.1 \%$ & $100.0 \%$ \\
\hline \multirow[t]{2}{*}{ Total } & Frequency & 316 & 64 & 6 & 10 & 2 & 12 & 410 \\
\hline & Percentage & $77.0 \%$ & $15.6 \%$ & $1.5 \%$ & $2.4 \%$ & $0.5 \%$ & $2.9 \%$ & $100.0 \%$ \\
\hline \multicolumn{9}{|c|}{ Skin color / Ethnic group } \\
\hline & & Yellow & White & Black & Brown & & & \\
\hline \multirow[t]{2}{*}{ No } & Frequency & 1 & 110 & 6 & 14 & 131 & & \\
\hline & Percentage & $0.8 \%$ & $84.0 \%$ & $4.6 \%$ & $10.7 \%$ & $100.0 \%$ & & \\
\hline \multirow[t]{2}{*}{ Yes } & Frequency & & 193 & 8 & 14 & 215 & & \\
\hline & Percentage & & $89.8 \%$ & $3.7 \%$ & $6.5 \%$ & $100.0 \%$ & & \\
\hline \multirow[t]{2}{*}{ Total } & Frequency & 1 & 303 & 14 & 28 & 346 & & \\
\hline & Percentage & $0.3 \%$ & $87.6 \%$ & $4.0 \%$ & $8.1 \%$ & $100.0 \%$ & & \\
\hline
\end{tabular}

profession are the ones who never experienced low back pain or had it sometime but have recovered and have learned to prevent new episodes. ${ }^{34}$ Also, perhaps older drivers have more opportunities to choose their type of work by using more appropriate routes and selecting less stressful jobs; or, they may accept their problems more easily and report fewer pain complaints.

Concerning self-employed workers, although they do not receive the benefits reserved for employees, they might have other advantages. For example, they might better dis- tribute their working hours and leisure time, choose the type of work, and seek medical assistance at any time before the problem aggravates. Additionally, self-employed truck drivers might report fewer complaints in general, since they cannot count on any kind of help, unlike those who have a link with a company or a work team. We were not able not find any study in the literature addressing this issue.

The prevalence of low back pain in this study was similar to that found in the literature for truck drivers and was associated mainly with increased working hours. It is worth 
noting that it is difficult to compare the different studies described, since the methodologies employed are not the same; also, prevalence studies depend on some factors such as the number of new cases, migration of the subjects with the disease, and duration of the disease. All these factors can cause either underestimation or overestimation of the results. $^{4}$

In prevalence studies, it is not always possible to determine the relationship between the risk factors and the onset of the disease. ${ }^{15}$ However, in the present study, an increased number of daily working hours was associated with occurrence of low back pain, which is easy to explain because this factor is related to many others involving the professional activity of truck drivers, since their work concerns not only transportation, but also involves deadlines, either due to the perishable nature of some goods to be carried, or for financial reasons, since each hour of delay in delivering the goods means additional expenses for the truck driver, such as extra fuel, spare parts, and meals. Another factor that can make truck drivers extend their driving periods is the lack of appropriate places to stop, both concerning road conditions and lack of safety for the load being carried, the truck, and the driver himself. To all these factors add the concentration required by the act of driv- ing a motor vehicle. Keeping appropriate attention for a long period is psychologically and physically consuming, leaving the musculature-particularly the trunk musculature-tense due to the absence of proper relaxation periods. It can be also emphasized that the number of working hours is associated with other risk factors that are widely described in the literature, such as remaining in the seated position for a long period, being exposed to vibrations, excessively twisting and bending the trunk, and carrying heavy objects, since the higher the number of hours worked daily by truck drivers, the more they are exposed to these factors, the consequence of which is the risk of triggering low back pain.

\section{CONCLUSIONS}

- The prevalence of low back pain in the truck drivers included in this study was $59.0 \%$.

Of all the variables studied, the amount of daily working hours was the only one presenting association with the presence of low back pain.

- An increase of an average of about 1 hour of daily working time was significantly associated with the occurrence of low back pain, with an odds ratio 1,07.

\section{RESUMO}

Andrusaitis SF, Oliveira RP, Barros Filho TEP. Estudo da prevalência e fatores de risco da lombalgia em caminhoneiros do Estado de São Paulo, Brasil. CLINICS. 2006;61(6):503-10.

OBJETIVO: Investigar a prevalência da lombalgia em caminhoneiros e verificar os possíveis fatores de risco relacionados à presença da dor lombar.

MÉTODOS: Foi elaborado um questionário que abordou fatores pessoais como: idade, prática de atividade física e esportiva, hábitos gerais de saúde, questões relativas ao exercício profissional e fatores relacionados à lombalgia. Calculou-se também o índice de massa corpórea através da relação entre o peso corporal e o quadrado da estatura. Foram avaliados 489 caminhoneiros do sexo masculino e selecionados 410 para o estudo. A análise estatística foi dividida em duas etapas: análise descritiva dos dados e regressão logística binária, na qual a variável resposta (presença da dor lombar) foi associada às demais variáveis, a fim de verificar sua correlação com a lombalgia. 
RESULTADOS: Dos 410 caminhoneiros avaliados 242 apresentaram lombalgia, correspondendo a $59 \%$ da amostra e 168 não apresentaram dor lombar, correspondendo a $41 \%$ da amostra. Dentre os fatores estudados o único que apresentou correlação com a presença da lombalgia foi o número de horas de trabalho. Os demais fatores considerados associados ao risco não apresentaram correlação com a dor lombar.
CONCLUSÃO: A prevalência da lombalgia nos caminhoneiros foi $59 \%$. O número de horas de trabalho foi a única variável que apresentou associação com a ocorrência da lombalgia, sendo que para cada hora de trabalho diário, o risco de o caminhoneiro apresentar dor lombar aumenta $7 \%$.

UNITERMOS: Estudos transversais. Homens. Veículos automotores. Dor lombar. Fatores de risco.

\section{REFERENCES}

1. Beurskens AJ, De Vet HC, Koke AJ, Van Der Heijden GJ, Knipschild PG. Measuring the functional status of patients with low back pain. Assessment of the quality of four disease-specific questionnaires. Spine. 1995;20:1017-28

2. Fransen M, Woodward M, Norton R, Coggan C, Dawe M, Sheridan N Risk factors associated with the transition from acute to chronic occupational back pain. Spine. 2002;27:92-8.

3. Hoogendoorn WE, Van Poppel MNM, Bongers PM, Koes BW, Bouter LM. Physical load during work and leisure time as risk factors for back pain. Scand J Work Environ Health. 1999;25:387-403.

4. Loney PL, Stratford PW. The prevalence of low back pain in adults: a methodological review of the literature. Phys Ther 1999;79:384-96.

5. Santos KGLL, Silva MAG. A prevalência de lombalgia em mulheres praticantes de ginástica em academias esportivas. Fisioterapia. 2003; $4: 117-25$

6. Toda Y, Segal N, Toda T, Morimoto T, Ogawa R. Lean body mass and body fat distribution in participants with chronic low back pain. Arch Intern Med. 2000;160:3265-9.

7. De Vitta A. A lombalgia e suas relações com o tipo de ocupação, com a idade e o sexo. Rev Bras Fisioter. 1996;1:67-72.

8. MacFarlane GJ, Thomas E, Papageorgiou AC, Croft PR, Jayson MIV, Silman AJ. Employment and physical of future low back pain. Spine. 1997;22:1143-9.

9. Mannion AF, Muntener M, Taimela S, Dvorak J. A randomized clinical trial of three active therapies for chronic low back pain. Spine. $1999 ; 24: 2435-48$

10. Marras WS, Ferguson SA, Gupta P, Bose S, Parnianpour M, Kim JY, et al. The quantification of low back disorder using motion measures. Methodology and validation. Spine. 1999;24:2091-100.

11. Miyamoto M, Shirai Y, Nakayama Y, Gembun Y, Kaneda K. An epidemiologic study of occupational low back pain in truck drivers. J Nippon Med Sch. 2000;67:186-90.

12. Queiroga MR. Incidência e localização de sintomas de dor em motoristas de ônibus na cidade de Londrina. Rev Bras Saude Ocup. 2002;27:12132.

13. Roland M, Morris R. A study of natural history of low-back pain. Part I: Development of a reliable and sensitive measure of disability in lowback pain. Spine. 1983;8:141-4.
14. Papageorgiou AC, Croft PR, Ferry S, Jayson MIV, Silman A. Estimating the prevalence of low back pain in the general population. Spine. 1995;20:1889-94.

15. Burdof A, Naaktgeboren B, De Groot HC. Occupational risk factors for low back pain among sedentary workers. J Occup Med. 1993;35:121320.

16. Fernandes RCP. Lombalgia e trabalho:uma breve revisão. Rev Bras Saude Ocup. 2002;27:55-65.

17. Adams MA, Mannion AF, Dolan P. Personal risk factors for first-time low back pain. Spine.1999;24:2497-505.

18. Guo HR. Working hours spent on repeated activities and prevalence of back pain. Occup Environ Med. 2002;59:680-8.

19. Kelsey JL, Hardy RJ. Driving of motor vehicles as a risk factor for acute herniated lumbar intervertebral disc. Am J Epidemiol. 1975; 102:608-13.

20. Anderson R. The back pain of bus drivers. Spine. 1992;17:1481-8.

21. Magnusson ML, Pope MH, Wilder DG, Areskoug B. Are occupational drivers at an increased risk for developing musculoskeletal disorders? Spine. 1996;21:710-7

22. Mortimer M, Wiktorin C, Pernold G, Svensson H, Vingard E. MUSIC (Norrtalje Study Group, Musculoskeletal Intervention Center). Sports activities, body weight and smoking in relation to low-back pain: a population-based case-referent study. Scand J Med Sci Sports. $2001 ; 11: 178-84$

23. Hosmer DW, Lemeshow S. Applied Logistic Regression. New York: Wiley; 1989

24. McCullag P, Nelder JA. Generalized Linear Models. New York: Chapman and Hall; 1989.

25. Barreira THC. Abordagem ergonômica da LER. Rev Bras Saude Ocup. 1994;22:51-60.

26. Heliovaara M. Occupation and risk of herniated lumbar intervertebral disc or sciatica leading to hospitalization. J Chronic Dis. 1987;40:25964.

27. Krause N, Ragland DR, Greiner BA, Fisher JM, Holman BL, Selvin S. Physical workload and ergonomic factors associated with prevalence of back and neck pain in urban transit operators. Spine. 1997;22:211726. 
28. Riihimaki H, Viikari-Juntura E, Moneta G, Kuha J, Videman T, Tola S. Incidence of sciatica pain among men in machine operating, dynamic physical work, and sedentary work. Spine. 1994;19:138-42.

29. Eriksen W, Natvig B, Bruusgaard D. Smoking, heavy physical work and low back pain: a four-year prospective study. Occup Med. 1999;49:15560.

30. Goldberg MS, Scott SC, Mayo NE. A review of the association between cigarette smoking and development of nonspecific back pain and related outcomes. Spine. 2000;25:995-1014.

31. Hildebrandt VH, Bongers PM, Dul J, Van Dijk FJH, Kemper HCG. The relationship between leisure time, physical activities and musculoskeletal symptoms and disability in worker populations. Int Arch Occup Environ Health. 2000;73:507-18.

32. Miranda H, Viikari-Juntura R, Martikainen E, Takala P, RiihimakI H. Physical exercise and musculoskeletal pain among forest industry workers. Scand J Med Sci Sports. 2001;11:239-46.
33. Krause N, Ragland DR, Fisher JM, Syme SL. Psychosocial job factors, physical workload, and incidence of work-related spinal injury: a 5 year prospective study of urban transit operators. Spine. 1998;23:2507-16.

34. Porter JM, Gyi DE. The prevalence of musculoskeletal troubles among car drivers. Occup Med. 2002;52:4-12.

35. Ying X, Bach E, Orhede E. Work environment and low back pain: the influence as occupational activities. Occup Environ Med. 1997;54:7415

36. Leboeuf-Yde C. Alcohol and low back pain: a systematic literature review. J Manipulative Phys Ther. 2000;23:343-6.

37. Matsui H, Maeda A, Tsuji H, Naruse Y. Risk indicators of low back pain among workers in Japan. Spine. 1997;22:1242-8.

38. Han TS, Schouten JSAG, Lean MEJ, Seidell JC. The prevalence of low back pain and associations with body fatness, fat distribution and height. Int J Obes Relat Metab Disord. 1997;21:600-7. 